\title{
本縫ミシンにおける縫目構造と縫締りの解析"1
}

\author{
東京重機工業株式会社松原亭 \\ 東京大学工学部神保泰 雄
}

\section{ANALYSIS APPROACH FOR STITCH CONSTRUCTION AND STITCH TIGHTENING OF LOCK STITCH SEWING MACHINE*1}

\author{
By Toru Matubara ${ }^{* 2}$ and Yasuo Jinbo $* 3$ \\ "2 (Tokyo Juki Industrial Co., Ltd., Chofu City, Tokyo, Japan) \\ *3 (Faculty of Engineering, The University of Tokyo, \\ Bunkyo-ku, Tokyo, Japan)
}

\begin{abstract}
Conventionally, stitch quality has been evaluated visually. In this study, stitch structures are shown in terms of skeleton stitch models to obtain quantitative analysis of stitch tightness.

The analysis results show the following interesting stitch properties:

(1) Formation of good stitches largely depends on, besides balanced upper and lower threads tensions, the cloth tightness produced by interlaced upper and lower threads.

Accordingly to the analysis results, proper lower thread tension setting is important to get good cloth tightness which has traditionally been undiscussed.

A lower tension of the lower thread produces a rectangular stitch model, and a higher tension of the lower thread forms an oval stitch model.

(2) In sewing thin, medium, or thick material at a low speed, it has been found that there is a corelation of systematic parabolic regression between the upper and lower thread tensions that lead to formation of well-tensed stitches.
\end{abstract}

(Received July 14, 1983)

\section{1. 粕言}

維製加工は紻維製品が製造される最後の加工であり， ての工程を経ることにより，被服菜材が本来保有してい る物理的性質の值に变化を来たしたりして, 製品のでき ばえに大きく影響したりする。释製後の程目がその完成 品の消費価値を左右する程の役割を占めているだけに， 释目の品質向上と安定化が大きな問題である。

良好な繾品質之は，上下系のバランスがとれた縫目で あり、しかあ上下系による存締り具合が被䋖䌘物の物性 に適合している状態いう。したがって，薄い伸縮性の ある有地仙は伸び易い系を使用してふっくらとした縫目 をつくり，布縮みがなく，また布地を引張っても系が可

"「ての報文を「綎の工学的解析手法(第 2 報)，Technological Analysis of Stitching (Part 2)」とする。
れない状態であり，一方，厚い伸縮性のない布地には太 い系を使用し，強じんなしっかりした繾目をつくり，十 分な締めつけ強度をすたせた状態を意味するとととな る。要するに被繾製菜材の剛性，言い換えれば，䁏の強 さに応して良好な縫目は異なるから，それぞれに適した 布締り其合を設定する必要がある。

これまで，実際の縫目はよ゙のようなものか，望ましい 縫目とはどのようなものかと，艂製者もミシン技術者も 以前加とり組んで，縫目構造の定型化，あるいは数值 化が試みられてきている ${ }^{(2)}$ 。従来の縫目構造の定型化 の考え方は，系の消費量を計算する目的から出発してお り、被服設計上系の必要量を算出するため，繾目の幾何 学的構造から，長方形あるいは檍円形繾モア゙ルを基礎之 して計算した縫系消費量の理論值と，実験によって求め られた実験値を比較し，直線艇の場合の縫系消費量を得 
ようとしたあのであり，十分な桻構造に関する知見至得 ると至っていない。また繾締りの良否評洒は，とれまで 定性的にはすっばら目視によりなされ，定量的には縫長 さ一定長に招ける上下采比率化上る䋖締り計算の力法加 用いられているだけである。しかしての方法は，上下系 の縫バランス，すなわち上下采の均衡縫条件がかかるだ けで，布締り具合学評洒することはできない。䋖品質の 泙価には二つの要素，すな扔ち上下系の平衡具合上布締 り具合とが不可欠である。との二つの要素が満足されて てそ初めて良好縫といえるのである。そてで本研究では との二つの縫締り具合を評価するための新しい縫目满造 モデルを提案する。そして，そのもデルを用いた縫目の 構造解析について得られた二，三の知見についてる報告 する。

2. 縫目構造のスケルトンモデル化と 䋖締りの解析

2.1 桻目構造のスケルトンモデル化の考え万 本研究は，䋖目の幾何学的構造形態を代用特性化した スケルトンモデルに招加えて，槰締り具合它定量的に 評洒分析を可能ならしめたものである。すなわち，実際 の縫特性が一見して判断できるようにスケルトンモデル 化して，長方形縫モデルを標集縫目とし，それを基準に 実際の槰目のずれを百分率で評価し，上下系の均衡县合， 布の締り具合，布の縮み具合を比較分析しようとするす のである。この解析方法により，実際の縫目の形状がよ゙ の上うに複雑であっても，その特性だりを取りあげるの で、従来のごよく縫目を直接任定型化しようという考え 方之異なり，維目の解析がきか力て楽になり，いろいる の縫特性を見出すことに大いに役立った。

\section{2 標準㖓目と実際释目の定義}

これまで縫目の構造が長方形繾モデルとか、棈円形梿 モデルとか論ぜられてきたが，実際の䋖目は系で布が締 められるので, 図 1(b)の上うに楕円形に近い形になる。 とのとき消費された采の長さをそのままにして，長方形 に置きかえると，図 2(b)のでとく，上下糸とも中心線 までは達しないて上になる。この達しない程度が布の締 めつけ程度をあらわすとになるので，ての図のように 奏際に使われた系の長さで, 長方形を描いたすのをスケ ルトン縫目上名付けることにし，長方形縫モデル図 1

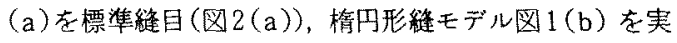
際縫目 (図 $2(b))$ と定義する。

\section{3 桻締り具合の特性值化について}

実際の縫目構造の縫締り具合を次に述へる縫締り率を 本ってあらわすてとにする。

図2 (a)，(b)において，一つの䊬目の上下系の消費量

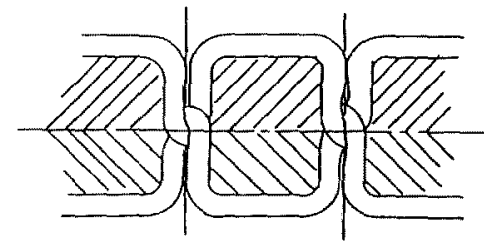

(a) Rectangular stitch model

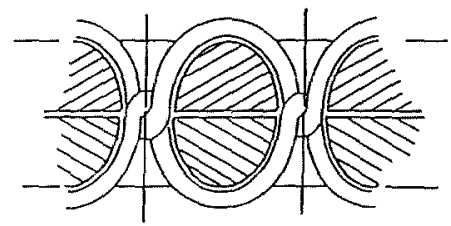

(b) Elliptical stitch model

Fig. 1 Types of stitch construction

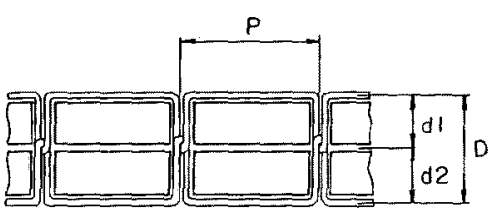

(a) Standard stitch

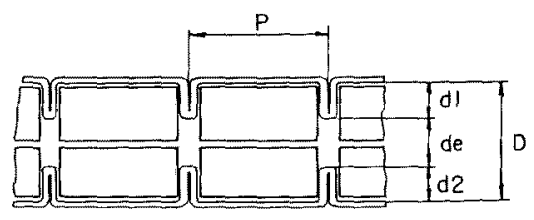

(b) Actual stitch

Fig. 2 Construction of skeleton stitch 加ら，それぞれ縫ピッチ分Pを差引いた残りの半分を、 上系締め代 $d_{1}$ ，下系締的代 $d_{2}$ ，また布の厚さ $D$ から上

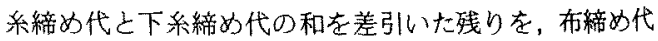
$d_{\mathrm{e}}$ とする。そして，布の厚さ住対するとれぞれの䋨的代 の比率を総称して縫締り率上よふてとにする。

縫締り率は次の三つをもって構成される。

$$
\begin{aligned}
& \text { 上系締り率 }=\frac{\text { 上系締め代 }}{\text { 布の厚さ }}=\xi_{1}=\frac{d_{1}}{D} \\
& \text { 下糸締り率 }=\frac{\text { 下糸締她代 }}{\text { 布の巢さ }}=\xi_{2}=\frac{d_{2}}{D}
\end{aligned}
$$




$$
\text { 布締り率 }=\frac{\text { 布締め代 }}{\text { 布の厚さ }}=\xi_{\mathrm{e}}=\frac{d_{\mathrm{e}}}{D}
$$

以上三つの繾締り率の分母は，本来の布厚さ上系の太 さを考慮したあのが望ましいのであるが，䋖締り具合を 巨視的に分析する本研究の立場加ら，系の太さを考慮す ることを省いた。

\section{3. 縫締り解析チャート}

\section{1 稌締り解析チャートの作成について}

前述したようにスケルトン化した縫目構造より，释締 り特性として縫䋨り率を定義したが，それを用いて夷際 儿䋖製条件扰よび，機械条件をい乃い万変化させて䋖締 りの解析を可能にしたチャートを，綘締り解析チャート と名称する。以下䋖䋨り解析チャートの作成方法老記述 する。

\subsection{1 実験方法}

被維布を図3の大きさに必要枚数 $m$ を切り取り，重称 て揃える。このとき布地の厚さをdとすれば，被縫布厚 さは $D=m d$ となる。

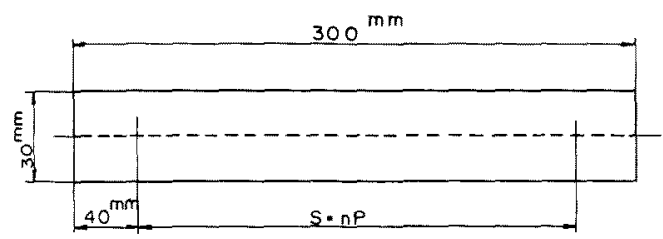

Fig. 3 Test material piece

布を試験故数 $m$ だけ重ね，中央試験系を用いて繾ピ ッチャで直線縫を行なう。縫った後，左端加ら $40 \mathrm{~mm} の$ 所加右へ針数 $n$ だけの繾長さを測定し $S$ とする。次に Sの長さの部分を切り取り，上系下系をはぐして，それ それれの長さを $L_{1}, L_{2}$ とする。乙の場合布の縫縮みがな いものとするので、縫った長さはそのまま䊗ピッチと、 释った針数の相乗積である。

\section{1 .2 討算方法}

$\begin{array}{ll}\text { スケルトン縫モデル图 } 2(b) \text { から } \\ \text { 布の厚さ } \\ \text { 上系の縍め代 } & d_{1} \\ \text { 下系の縍め代 } & d_{2} \\ \text { 布の締め代 } & d_{\mathrm{e}}\end{array}$

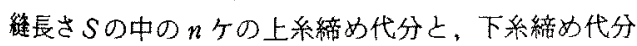
の長さは、それぞれ，

$$
L_{1}-S=2 d_{1} \times n, L_{3}-S=2 d_{2} \times n
$$

であるから、

$$
d_{1}=\frac{L_{1}-S}{2 n}, d_{2}=\frac{L_{2}-S}{2 n}
$$

したがって。

上系締り率は， $\xi_{1}=\frac{d_{1}}{D}=\frac{L_{1}-S}{2 n D}$

下系樀り率は， $\xi_{2}=\frac{d_{2}}{D}=\frac{L_{2}-S}{2 n D}$

有締り率は， $\xi_{\mathrm{e}}=\frac{d_{\mathrm{e}}}{D}=1-\left(\xi_{1}+\xi_{2}\right)$

し計算される。

\section{4. 低速領域の中厚物艂における 上下糸張力変化の糐締り解析}

3.1亿述べた繾䋨り解析方法にもとつき，低速領域の 中厚物縫に㧍いて，下記の実験条件で縫実験を行ない， 縫締り解析チャートを作成し，それ比上り縫締り变動の 解析在行なった。

\section{1 実験条件}

\subsection{1 艂製条件}

$$
\begin{array}{ll}
\text { 布 } & \text { 棉ブロード2 枚(布厚 } 0.41 \mathrm{~mm} \text { ) } \\
\text { 系 } & \text { 綿繾系 \# } 50 \\
\text { 縫ピッチ } & 2 \mathrm{~mm}
\end{array}
$$

\subsection{2 機械条件}

ミシン 家庭用ミシン(東京重機 $\mathrm{Hz}-5000$ )

綎速度 400 針/分

下系張力 $3 \mathrm{gf}, 5 \mathrm{gf}, 7 \mathrm{gf}, 10 \mathrm{gf}, 15 \mathrm{gf}, 20 \mathrm{gf}$ 上系張力 上系調子ダイヤル目盛(1)から(9)まで変化 押え圧 $1.5 \mathrm{kgf}$

系取りば权の強さ ストローク $8 \mathrm{~mm}$ 初期張力 $15 \mathrm{gf}$

押兊の種類 直線縫用押元

\section{加全回転加ま}

とこに上記の下系張力とは，ボビンケースに下杀ボビ ンを入れて，系をボビンケースばねから引き出すときの 張力の大きさ索いい，また，上系張力とは，系卷き加ら 系を各系案内，調子四任上招して，天びん側の方に引き 出すときの張力の大きさをいう。

\section{2 実験結果}

4.2.1上系調子ダイヤル目盛と上系張力の大きさに xい

㘡 4 は，家庭用 シシン(東京重機 $\mathrm{Hz}-5000)$ ，表 1 の各種の系をとおして，上系調子ダイヤル目盛を(1)ら (9)まで変化させたときの，上系張力の実測做である。

図 4 でわかるように, 表1亿示した各種類の系に対し て，上系張力の大きさは，上系調子ダイヤル目盛変化よ りそれぞれ增加するが，その値はある狭い幅の範囲の中 に入っていることが明らかである。

以下述べる縫実験結果に扮いて，上系張力は本来无の 


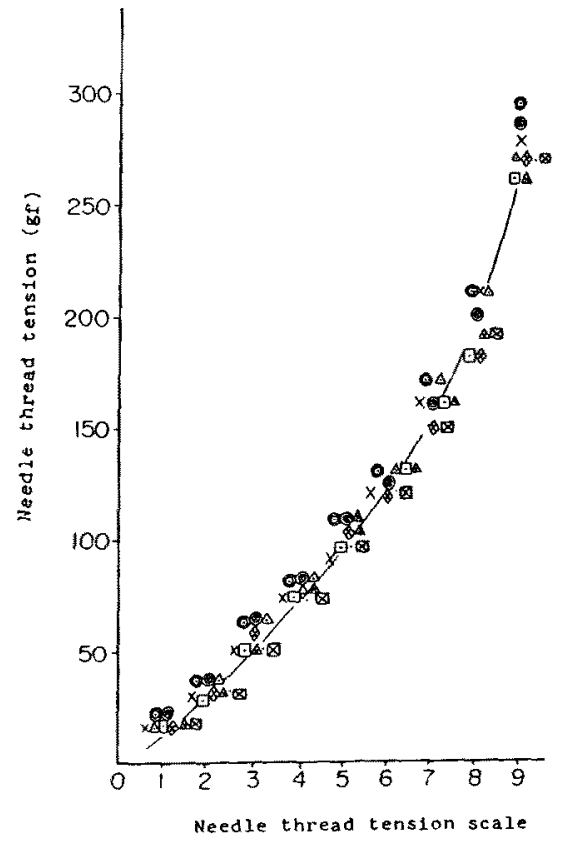

Fig. 4 Needle thread tension scale vs. Needle thread tension for each type of thread

Table 1 Symbols of test sewing threads

\begin{tabular}{|l|c|c|}
\hline Cotton sewing thread & $\# 30$ & $\odot$ \\
\hline Cotton sewing thread & $\# 50$ & $\triangle$ \\
\hline Cotton sewing thread & $\# 80$ & $\times$ \\
\hline Waxed cotton sewing thread & $\# 50$ & $\square$ \\
\hline Silk sewing thread & $\# 50$ & $\cdot$ \\
\hline Polyester spun sewing thread & $\# 60$ & $\diamond$ \\
\hline Nylon filament sewing thread & $\# 80$ & $\bigotimes$ \\
\hline Nylon filament sewing thread & $\# 50$ & $\triangle$ \\
\hline Polyester filament sewing thread & $\# 40$ & $\odot$ \\
\hline
\end{tabular}

大きさを直接表わすべきであるが，本研究の目的が、縫 特性在已視的に把握するという立場から，実験の便宜上 上糸調子ダィヤル旦盛をその代用特性值しして用いるこ しにした。

\subsection{2 下系張力每に括ける上系張力変化の觡締り解 析千ャ一ト}

匈 5-1，2，3，4，5，6は，4１0実験条件に批い, 下系張力ををれぞれ $3 \mathrm{gf}, 5 \mathrm{gf}, 7 \mathrm{gf} ， 10 \mathrm{gf}, 15 \mathrm{gf}, 20$ gf K設定し，上䗅力をそれぞれ上杀調子ダイヤル目 盛@から@まで变化させて綎実験を行ない，3.1.20計

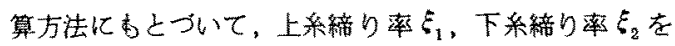
算出し，絴締り解新チャートを作成したあのである。

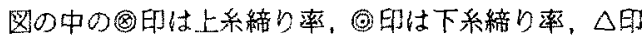

For $3 g$ f bobbin thread tension.

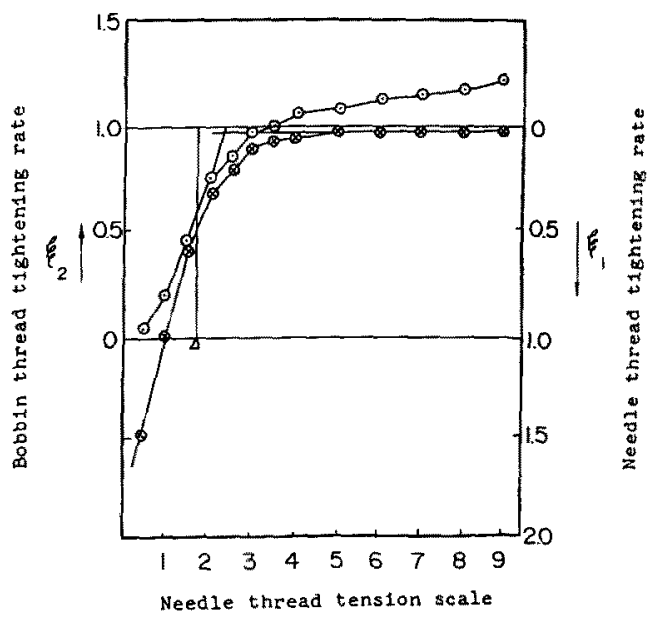

Fig. 5-1 Analysis chart of stitch tightness in sewing medium-weight material

$\otimes$ Needle thread tightening rate

$\odot$ Bobbin thread tightening rate

$\triangle$ Balanced stitch, $\xi_{1}=\xi_{2}$

Por $5 g$ f bobbin thread tension.

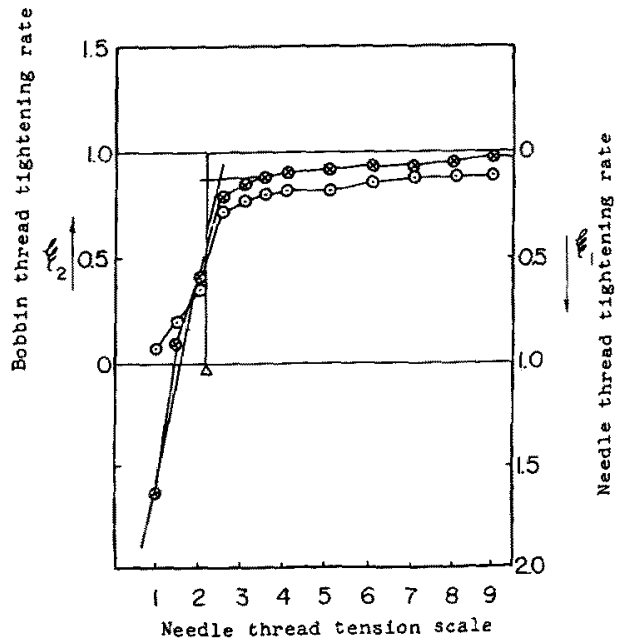

Fig. 5-2 Analysis chart of stitch tightness in sewing medium-weight material

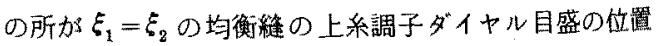
梦吉。

\section{3 考 察}

䋖害験に上り得られた維繶り解析チャート区5のそれ ぞれより考察した結果，中军物綎におりるいるいるの綎 特性が存在することがかかった。以下をれらについて詳 
For $7 g f$ bobbin thread tension.

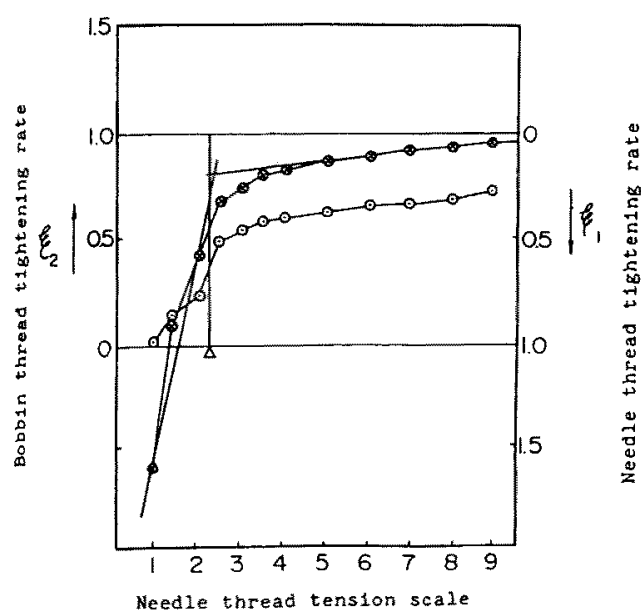

Fig. 5-3 Analysis chart of stitch tightness in sewing medium-weight material

for $10_{5} \mathrm{f}$ bobbin thread censton.

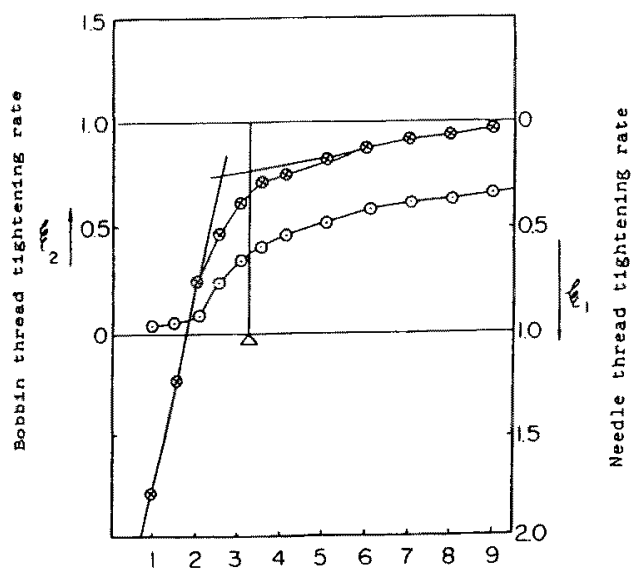

Needle thread tension scale

Fig. 5-4 Analysis chart of stitch tightness in sewing medium-weight material.

絸任説明する。

4.3.1下系張力の大きさと，実験の縫目構造および 䋖締り具合

（1）下系張力が $5 \mathrm{gf}$ のごく小さい範囲では、図 5-1 でかるように，上系張力のわずかの变化で，下吊維か ら上吊繾まで変化するので，実際の綎調整は非常に微妙 である。普通とのような下系張力の低い範囲は用いられ ていないし加しての下系張力に見合った上䗅力によ

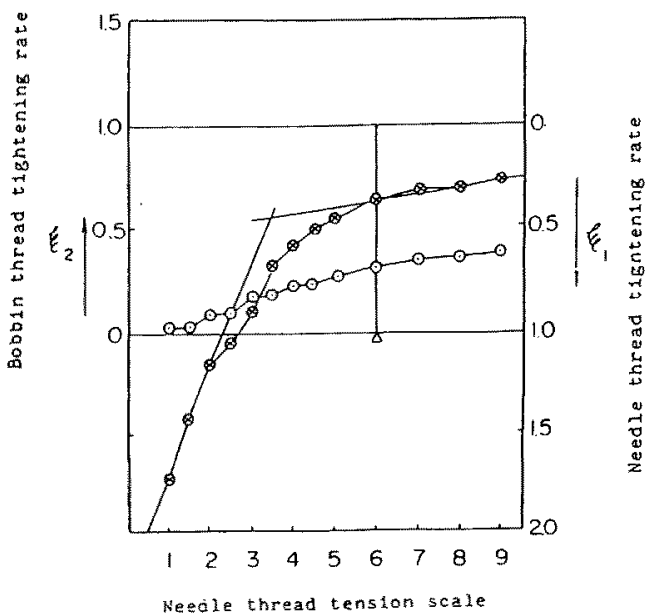

Fig. 5-5 Analysis chart of stitch tightness in sewing medium-weight material

Fof $20 \mathrm{gr}$ booiln thread tension.

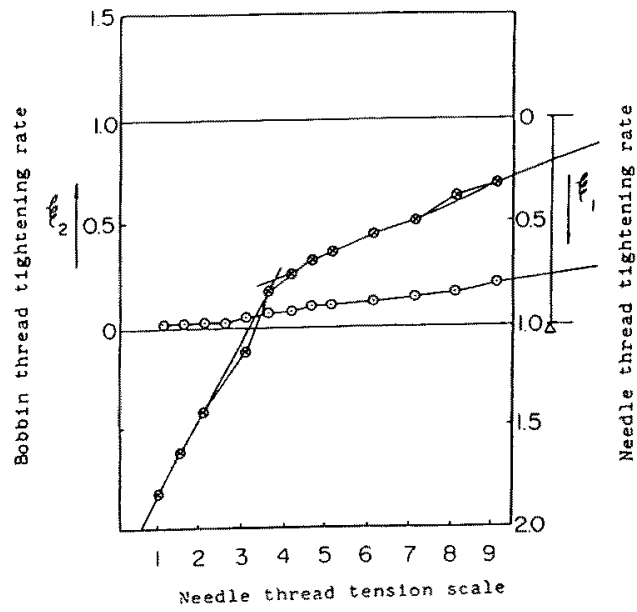

Fig. 5-6 Analysis chart of stitch tightness in sewing medium-weight material

っててきあがる均衡艇心槰目構造は，布締り率む小さく， 典型的な長方形䋖モデルである。

（2）下系張力が $10 \mathrm{gf}, 15 \mathrm{gf}$ 上大きくなるにつれ，図 5-2，5-3でわかるように，䋖目構造は栺円形縫モデル に変化してくる。との条件では，下吊䋖から上吊縫まで の上系張力均衡链のための籍囲はかなり広く、織調整も 楽である。この範囲の下手張力の大きさが一般的に使用 されている。しかしての縫目楛造は，布締り率㐘大きく， 
縫締り具合もややかたく、布縮みも出やすくなっている。

(3) 下系張力が $20 \mathrm{gf}$ 以上になる之，四 5-4でわかる 上うに，上系張力を相当強くしても下締り状態であり。 上下系均衡檤まで䋨如あげるためには，上系張力は相当 強くしなりればならなくなる。艂目構造は完全偏平形繾 モデルとなり，布楴り率すきわわて大きい。この縫目は かたく，布縮者著しくなり，やわら加な布地仙好ま しくないあのである。

以上加ら加加ととは，下系張力の大きさが，長方形 縫モデルのようなやわらか心繾目加ら，偏平形絴モデル のようなかたい縫目まで，各種縔目構造を形成する基本 の条件となっているとよである。てれを䋖締り解析チャ 一ト上加ら表現すると，下糸張力の大きさが布締り率 $\xi_{\mathrm{e}}$ の大きさを決定する大きな要因であるというととで ある。

\subsection{2 上系締り率変化の特性}

図50下系張力拈上び上系張力の大ささの变化におけ る、上系締り率の变化をみる上, 上系張力の低い領域で は急上昇の面線变化をなし，その高い領域では叻やか な勾配の直線変化をなしており，その中間の領域では， 陆者のそれぞ曲線变化をなしていることがわかる。そ して全体として，下系張力の大きさに加わらず，す心゙ て双曲線状となっていることが大きな特色である。これ を考察するのに，上張力が变化する之，始奴ルピ ング状態であり，それから下吊繾を経て上吊綘に移行す るのであるが，上下系交絡する以前は，上系ループが下 系張力に全く影響を受けずに締如られ，上下系の交絡す るととあに，互いに締めつけ合い上系縍り率の变化は連

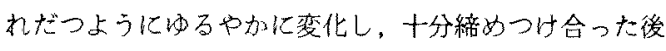
は，上系張力をいくら增加しても上系䋨り率はほとんど 変化せず，水平沂い状態となっている。

困6は、縫繶り解析チャートの一般例であるが, 上采

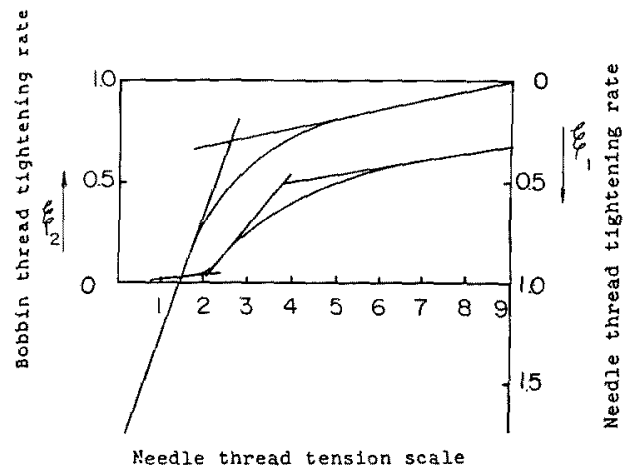

Fig. 6 Analysis chart of stitch tightness in sewing medium-weight material
締り率变化線は下采張力の大きさにかかわらず，すべて の折線状の变化の特性をむって晾り，下系䋨り率変化線 は下系張力の大きに加からず，すべての二重折線状 の变化の特性をもっている。特に，上糸締り率变化線の 上系張力の低い領域之高い領域のそれぞれの直線变化 は，上采締り率婆化線全体に対して，渐近線状の性質を もっている。

4.3.3 各下系張力の大きさでとの上系縍り率変化線 群の特性

図7は、下糸張力の $3 \mathrm{gf}, 5 \mathrm{gf}, 7 \mathrm{gf}, 10 \mathrm{gf}, 15 \mathrm{gf}$, $20 \mathrm{gf}$ の場合上系締り率変化線によってつくられた濑近 線をまとすて描いた線图である。乙れを子細炕検討する 之, 上系締り率变化線汅上る漸近線の交点は下采張力の 大きさの順序にある傾きをあった一直線上住置すると とが扔かった。これは繾滴り変化が下系張力の大きさで とにやはり規則正しく行なわれているととを示すおので ある。

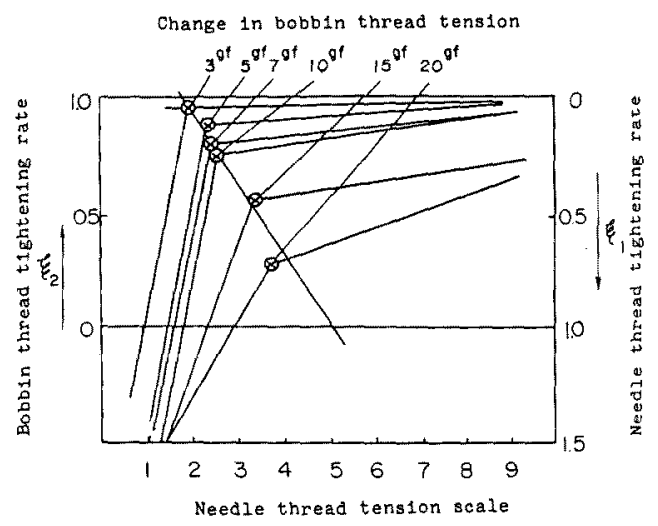

Fig. 7 Needle thread tightening rate characteristics in sewing medium-weight material

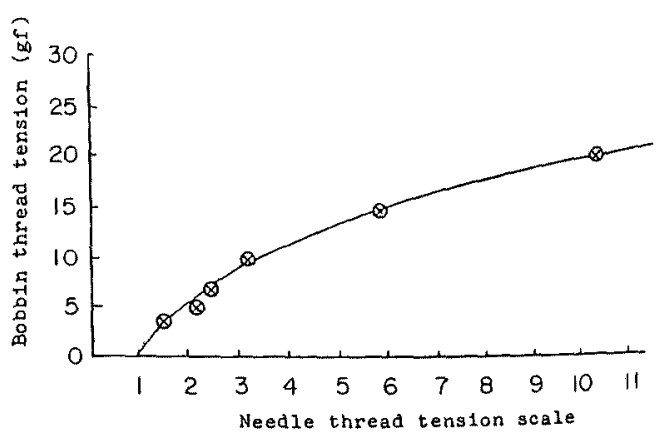

Fig. 8 Correlation between the needle thread and bobbin thread tensions of a balanced stitch in sewing medium-weight material 
4.3.4 上下均衡释における上下系張力の大きさの相 関飞ついて

叉8は，各下系張力の大きさどとに，上系張力を变化 さ甘て作成した释締り解析チャートから， $\xi_{1}=\xi_{2}$ の均衡 路(图 $50 \triangle$ 月の位置)における上下系張力の大きさい相 刘関保考線図にしたものである。図8において，上下系 張力の大きさの間には，明ら玑放物線回帰の相関の特 性が存在するととがわかる。これは低速領域において， 程締り変化が上下系張力の大きさの変化に対して，規則 正しく行な狆ているととを示ずのである。

\section{5. 低速領域における薄物程，厚物䟺の解析}

4.30低速領域の中厚物維に拉ける綎締り解析の結 果，下系張力上上系張力の間にはきわめて規則正しい特 性のあることがわかったが，薄物栈，厚物綎の場合につ いて,同様調バてみた。

\section{1 実験条件}

\subsection{1 䋖製条件}

(1) 薄物䋖

\begin{tabular}{|c|c|}
\hline 布 & レーヨン平織 2 枚(布得さ $=0.19 \mathrm{~mm}$ ) \\
\hline 釆 & ナイロンフィラメント縫采＃100 \\
\hline 針 & $\# 11$ \\
\hline 綎ピッ千 & $2 \mathrm{~mm}$ \\
\hline 厚物維 & \\
\hline 布 & コート地 2 枚（布厚さ =0.9 mm） \\
\hline 系 & 綿释系＃50 \\
\hline 錗 & $\# 14$ \\
\hline 梿ピッチ & $2 \mathrm{~mm}$ \\
\hline
\end{tabular}

\subsection{2 機械条件}

4.1.2 k同じ

\section{2 実験方法}

5.10実榇条件で，3.1.10実験方法にも上ついて释 実験老行ない作成した綎楴り解析千ャ一ト加ら，中覃物

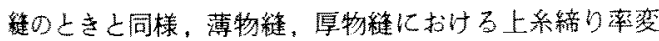
化線の特性図上，上下系均衡維の上下采張力相関四在作 成した。

\section{3 実跧結果}

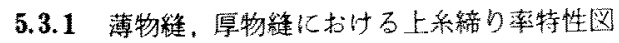

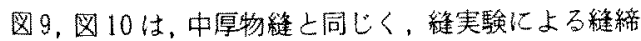
り解析チャート加ら，それぞれの上糸締り率变化線を上 り出して漸近線を描いた線図である。

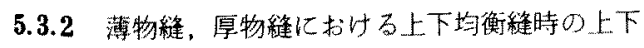
系張力の相関図

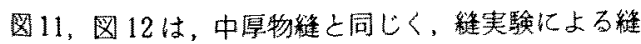
䅧り解析チャートから $\xi_{1}=\xi_{2}$ の上きの下糸張力上上系 張力の相関を楾図にしたすのである。

\section{4 考 察}

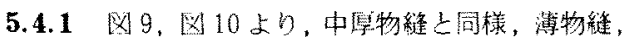

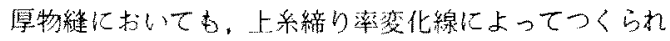

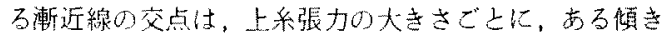

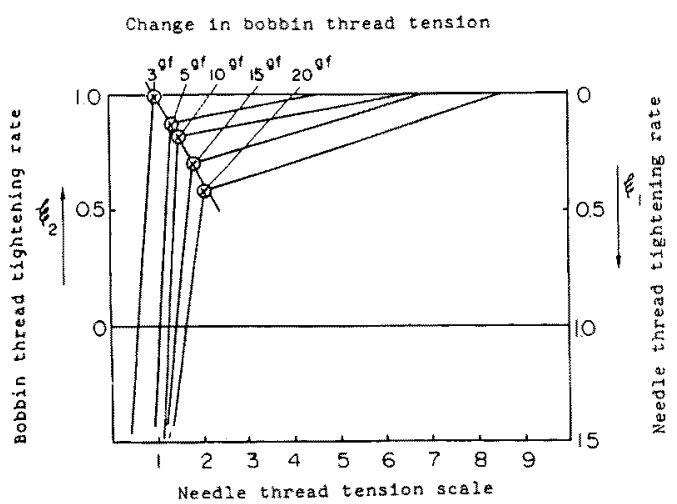

Fig. 9 Needle thread tightening rate characteristics in sewing light-weight material

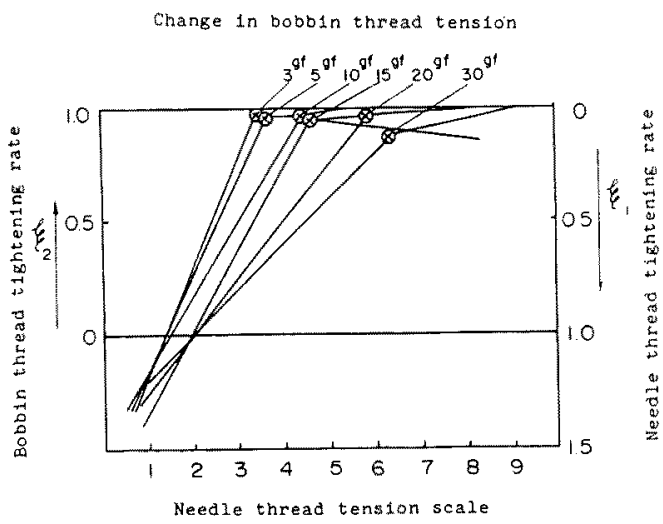

Fig. 10 Needle thread tightening rate characteristics in sewing heavy-weight material

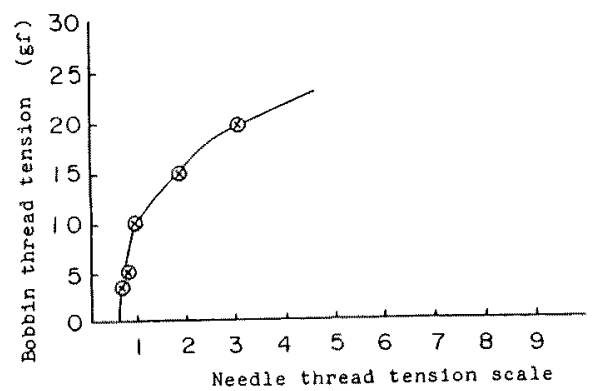

Fig. 11 Correlation between the needle thread and bobbin thread tensions of a balanced stitch in sewing light-weight material 


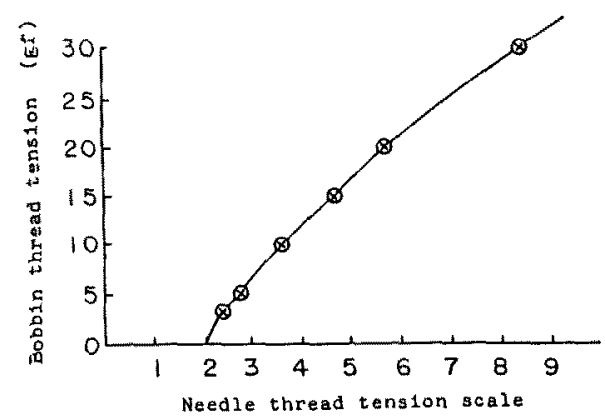

Fig. 12 Correlation between the needle thread and bobbin thread tensions of a balanced stitch in sewing heavy-weight material

をあった直線上にありその直線は特に薄物綎の場合に は非常に勾配の強いものであり，愿物䋖の場合には水平 に近いあのであるととがかかった。

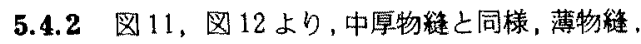

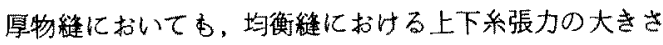
の間にはそれぞれ異なった形状であるが、放物線回㷌の 相関特性があるととがわかった。

\section{6. 結言}

说来縫目の良否を評価するのに，目視判断などで行な っており，舴特性が不明確であったが、本研究では、艇 目構造を代用特性化したスケルトン縫モデルに扰きかえ

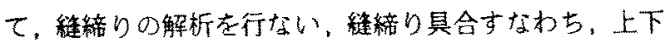
系均衡县合，布䅧り具合を分析して，低速頌域では多く の眮味ある縫特性を見出すことができた。 その結果老次汇まとめて述べる。

\section{1 良好䋖のための布檬り具合条件の重要性}

良好な維目を得るには，上下系の均衡縫の条件之，更 に上下糸の布締り具合の条件と二つの要素加考元る必 要がある。今まては上下系の均衡状態のみ詥しられてき たが、綎製条件、すなわ素材の種類、繾製製品の用途 によって良好な縫目を作るのには，布締り具合を重視し なりればならないことがわかった。そのためには下采張 力の大きさの設定がきわめて重要なのである。

\section{2 下糸張力の大きさと維目棈造の相関につい} $\tau$

縫目構造すなわち繾締り具合を左右するのは，䋖製条 件、機械条件を含めて，むっばら下系張力の大きさであ る。下系張力が低いときは，長方形綎モデルに近いやわ らかい䋖目が得られるが，均衡䋖のための上系張力の籍 囲が非常に狭い。下系張力が高いときは，棈円形縫モデ ルのかたい繾目になるが，均衡綎のための上系張力の籍 用がかなり应くなる。

このことは薄物䋖では，一般にやわらかい縫目を得る ために下系張力を低くして䋖うが、上系張力の調節が非 常比敏感でなかなか調節しにくいととや，また厚物䋖で は一般にかたい縫目を得るために下系張力を強くする が，上系張力の調節が非常に楽であるという一般縫製者 の意見を完全に襄づるあのである。

\section{3 低速領域における規則的な䋖楴り特性}

低速頼域においては，薄物縫，中厚物縫，厚物鐩何九 の場合にあ，規則的な释締り変化がある。すなわち，上 下系均衡䋖に斿ける上下系張力の大きさの間には，放物 楾回㷌の相関があるとと。

また，下䜌力ごとの上系締り率変化線によってつく られた漸近線の交点群は，古る㑯きをもった直線上伅あ り、この直楾の勾配は布の厚さに非常に高い相関加ちる $\check{と}$ と。

てれまで䋖はつかみにくく，解析がむずかしいとされ ていたが、下系張力、古るいは上系張力の大きさの変化 にしたがって、規則正しい変化をするてとなどか明らか になった。

付記：本研究の一部は，織維学会，昭和 58 年度年次 大会研究発表会に扔いて発表したものである。

なお，本論文は筆者の東京大学憲查学位論文の一部で ある。

\section{女献}

1) 河内保二: 絩維科学, Vol.1，4，(1981)

2) Dna O'Dweyer, D. L. Munden: Clothing Res. J., 3, 1 (1975)

3)上野，田中: 織維工学，Vol.31，No.4 (1978)

4) 安哈, 岩神: 蟣消誌, Vol.23, No. 1(1982)

5) 堀野，川西：䋐消誌，Vol.10，No.1(1965)

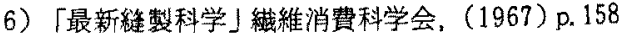

